\title{
DESIGN AND DEVELOPMENT OF A LOW COST SEMI-DIRECT TYPE COPRA DRYER
}

\author{
Eutiquio E. Sudaria ${ }^{1}$
}

\section{INTRODUCTION}

\section{Importance:}

Coconut farmers in the Philippines use different types of copra dryer in copra processing. Copra quality and income are very much affected by the type of dryer used. In the country, there are indirect, direct, and semi-direct type dryers. The common types of dryer used by the coconut farmers especially in the Visayas are direct and semi-direct ones. There is high probability of the direct dryer together with the copra in getting burned because the firing place is directly under the drying platform where the coconut meat is placed. Especially if the meat is reaching $10 \%$ or lower moisture content where oil is coming out and the fire is immediately under it. Semi-direct type dryer is quite comfortable to use having the less probability of burning the copra and the dryer because the firing place is away from the drying platform. The firing place is only linked to the drying platform by a tunnel.

The present problems of the existing semi-direct type copra dryers are unequal heat distribution on the drying platform, fuel consuming, less capacity, and expensive. The most serious defect observed by the author is the unequal distribution of heat on the drying platform. The existing semi-direct dryers have the hottest portion at the farmost part of the drying platform from the firing place. This dryer defect required the coconut farmers more time and fuel to produce good quality copra.

\section{Objectives:}

1) To design and develop a low cost semi-direct type copra dryer.

2) To evaluate the performance of the designed dryer.

\section{MATERIALS AND METHODS}

\section{Design Considerations:}

The semi-direct dryer was designed based on the following considerations: a) low cost, utilizing the materials available in the locality; b) has a capacity of 2,000 nuts; c) the heat distribution on the drying platform shall be more or less equal; and d) fuel saving.

\section{Dryer Design and Construction:}

Figure 1 shows the orthographic view of the semi-direct type copra dryer. The drying platform has a floor area of $2.4 \mathrm{~m} \times 3 \mathrm{~m}$ and sidings of $0.50 \mathrm{~m}$ high. The tunnel connecting the firing place to the pienum chamber below the drying platform has a length of $3 \mathrm{~m}$. The first $2.2 \mathrm{~m}$ length has a cross section of $3 / 4 \mathrm{~m} \times 3 / 4 \mathrm{~m}$, and inclined at a slope of $15 \%$. The tunnel gradually enlarges towards the plenum chamber. The firing place is $3 \mathrm{~m}$ away from the front edge of the drying

\footnotetext{
${ }^{1}$ Assistant Professor III, Regional Coconut Research Center, Visayas State College of Agriculture, Philippines.
} 
platform. A shed was provided in order to let the processing continue even during rainy days. The climensions of the shed are shown in Fig. 2. The materials used were coconut lumbers for both the dryer and the shade. Bamboo slats were used for the floor of the drying platform and coconut leaves for the roof. The cost of materials and labor was P3,500.00 as of December 1992.

\section{Performance Evaluation:}

After the construction of the dryer, it was tried to check its functionality especially the heat distribution on the drying platform. It was modified and tested until it was ready for the proper evaluation.

The dryer was evaluated with three replications using 2,000 mature nuts (Baybay Tall) per replication. The 2,000 nuts were dehusked, splitted, and piled at the drying platform. The arrangement of the splitted nuts on the drying platform was patterned from the farmers' style as confirmed better by Ly, et al. (1979) where the coconut halves were arranged vertically (Fig. 3).

\section{RESULTS AND DISCUSSION}

\section{The Dryer:}

The perspective view of the dryer with shed is shown in Fig. 4. The dryer and the shed were made out of four mature coconut trees sliced into different required sizes. The roof was made also of coconut leaves. In constructing this dryer in the mountain, the only material that was not avallable in the construction site was the common wire nails. This is very appropriate in the Philippines especially in Eastern Visayas where the topography is very irregular and coconuts are growing in the mountains.

The dryer was constructed in a rolling terrain around $20 \%$ slope and in a flat land. As of December 1992 in Baybay, Leyte, there were already six and one semi-direct type dryers of this design constructed and used in rolling and flat areas, respectively. The performance of the dryer in flat and rolling areas was the same. However, minor adjustment in the plenum chamber was made for the dryer constructed in the flat land.

During the development stage, the size of the tunnel, the degree of inclination, and the shape of the plenum chamber affected the heat distribution on the drying platform and time of drying. The tunnel connecting the firing, place and the drying platform has a unique shape. Its total length was $3 \mathrm{~m}$. It was divided into two sections as shown in Fig. 1. From the firing place, the length $2.2 \mathrm{~m}$ has a cross section of $0.75 \mathrm{~m} \times 0.75 \mathrm{~m}$. The remaining $0.8 \mathrm{~m}$ going to the drying platform has an enlarged cross section. The reason behind this was that when the cross section is srxiall, the air velocity is fast and when the cross section is large the air velocity is slow. Since the desired hot air distribution on the drying platform was uniform, the static pressure must be maximum at the plenum chamber and the velocity pressure must be minimal if not zero. That is why the size of the tunnel was made as such. At the entry point of the tunnel, the velocity pressure is maximum due to the small tunnel's cross section and static pressure is maximum at the point approaching the drying platform due to the enlarged cross section of the tunnel. As a result, heat distribution particularly the farthest and nearmost parts of the drying platform from the firing place have the uniform heat intensity unlike the existing farmers' semi-direct type copra dryers. However, when the size of the tunnel (the $2.2 \mathrm{~m}$ long) was too small tunnel's cross section and static pressure is maximum at the point approaching the drying platform due to the enlarged cross section of the tunnel. As a result, heat distribution particulary the farthers and nearmost part of the drying platform the firing place have the uniform heat intensity unlike the existing farmers semi-direct type copra dryers. However, when the size of the tunnel (the $2.2 \mathrm{~m}$ long) was too small $(0.3 \mathrm{~m} \times 0.3 \mathrm{~m})$, not enough hot air can enter thus the loaded 
coconut halves for copra were uncooked. On the other hand, when the size of the tunnel was too large, there was no good hot air entry producing an intermittent and varying heat distribution on the drying platform. That's why the size selected was $0.75 \mathrm{~m} \times 0.75 \mathrm{~m}$.

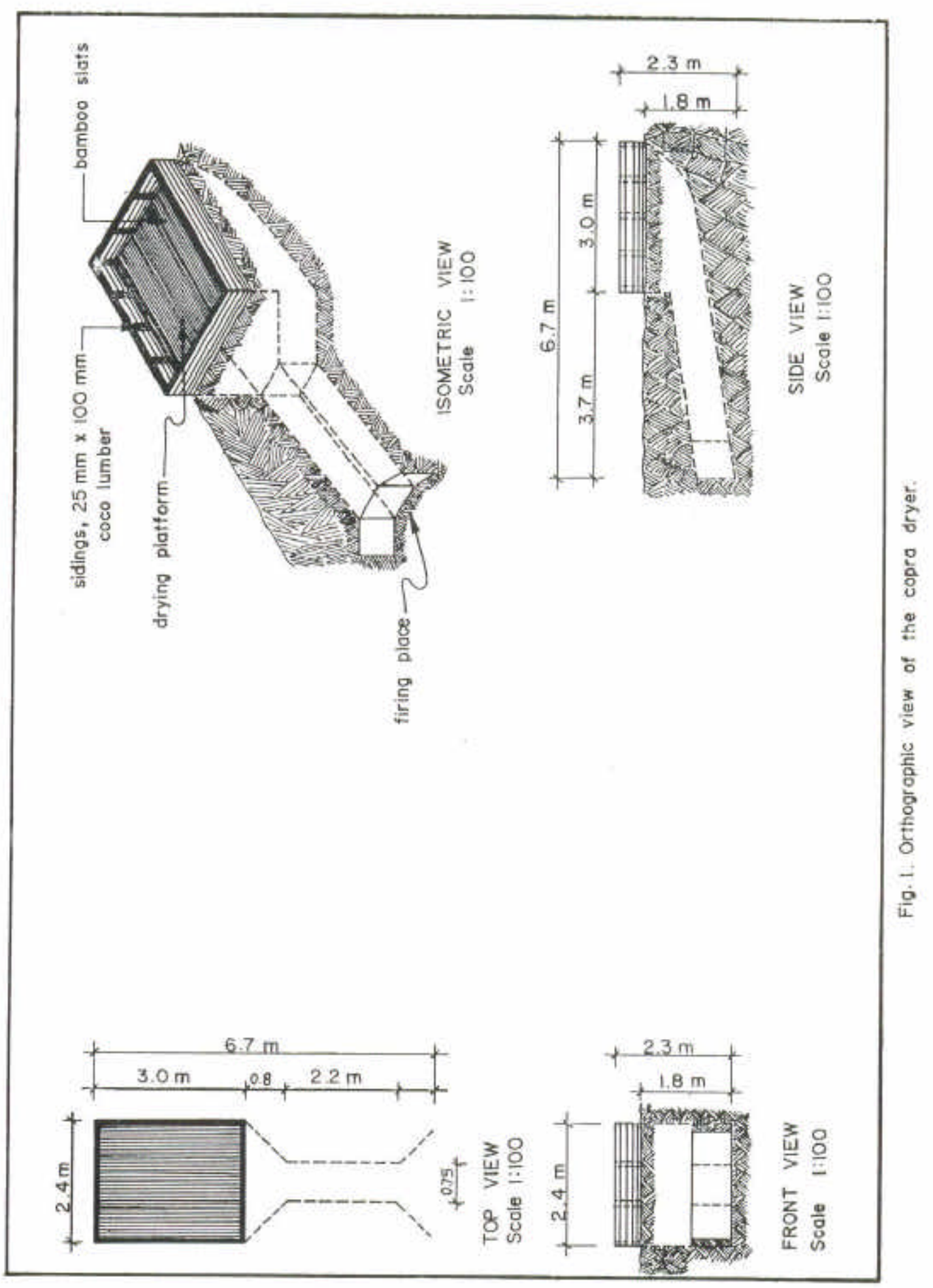




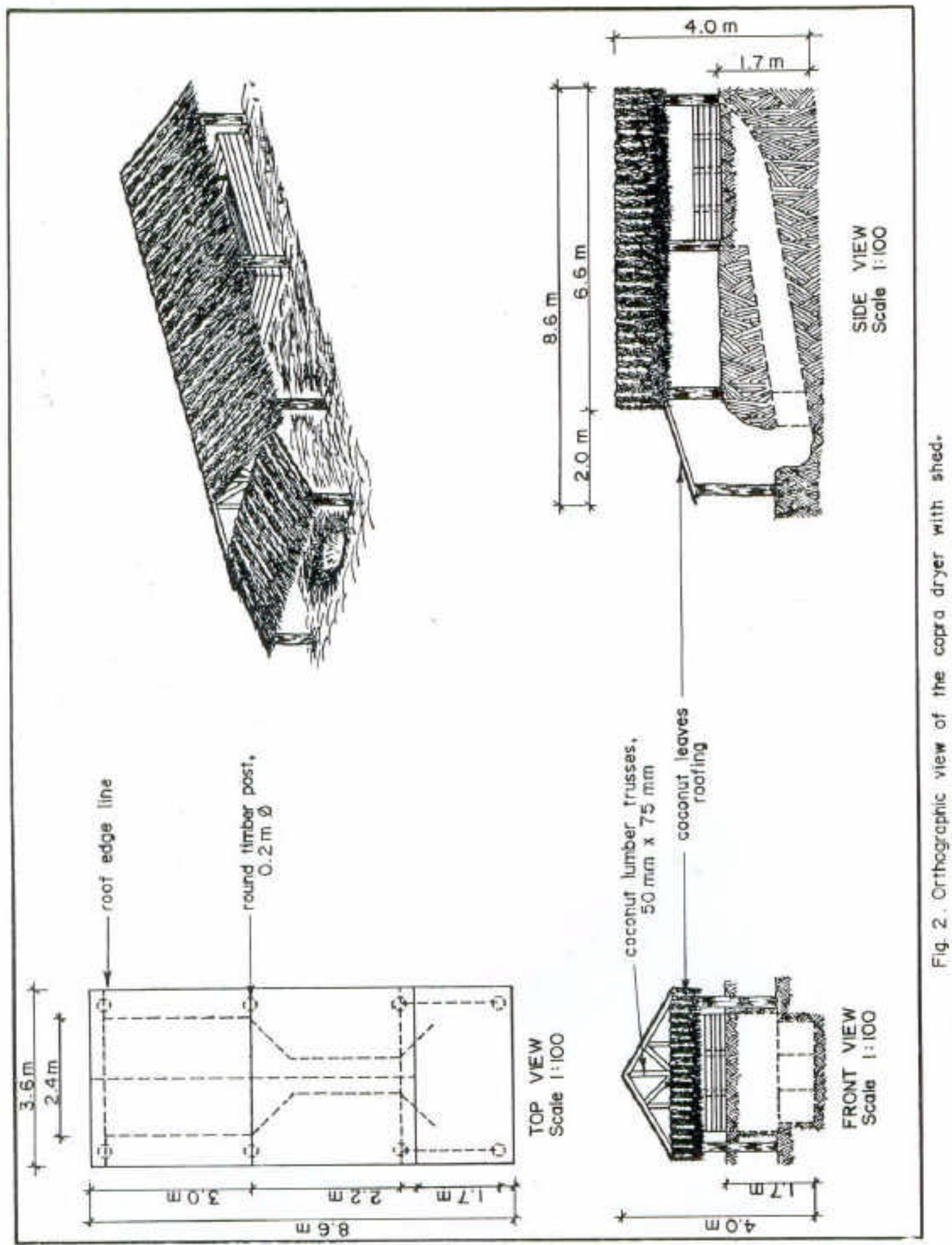



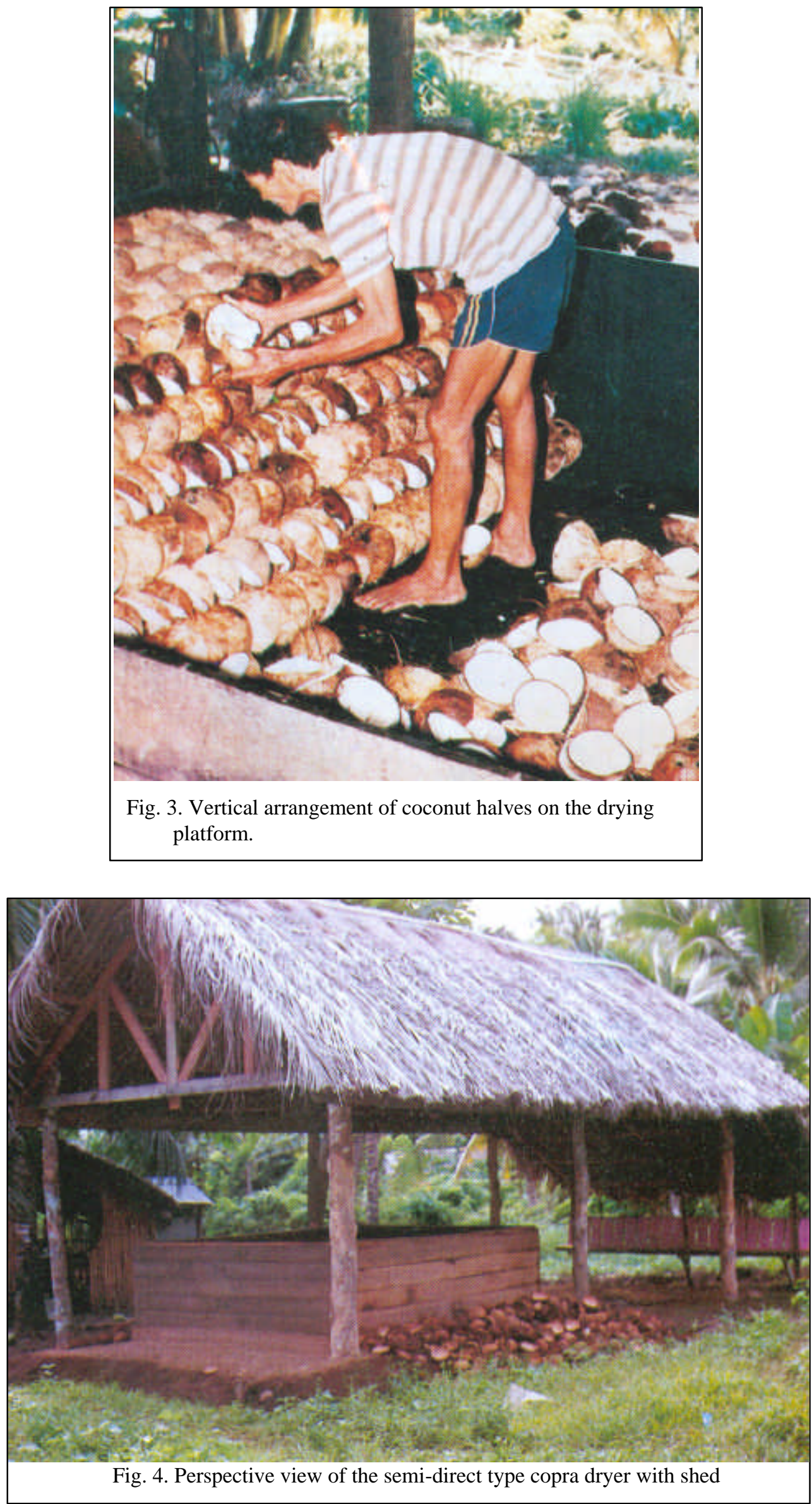
For the tunnel inclination,below $15 \%$ is not recommended because when the wind blow into the tunnel the ignited fuel in the firing place fly into the plenum chamber just immediately below the drying platform, thus burning might occur. Slope higher than $15 \%$ was alright.

The configuration of the plenum chamber was similar to a spoon. The center of it connected the tunnel to the firing place.

The dryer could be used to dry 500,1,000, 1,500, and 2,000 nuts at a time. More than 2,000 nuts could no longer be accommodated at the drying platform.

\section{Performance of the Semi-Direct Type Copra Dryer:}

The 2,000 nuts required 23 hours to reduce its moisture content to 9\% (Fig. 5). This was around three days. The first two days Were spent for firing the piled/arranged coconut halves on the drying platform. On the third day, the partially dried meat with shell on the drying platform were scooped and placed back to the dryer for another firing until cooked.

The variation of the temperature on the drying platform ranged from $3.5^{\circ} \mathrm{C}$. The temperatures generated on the drying platform during drying are shown in Fig. 6. It could be seen in the graph that the average drying temperatures fluctuated from 50 to $70^{\circ} \mathrm{C}$ in most of the times. However, the temperature at the bottom of the piled nuts on the drying platform reached $91{ }^{\circ} \mathrm{C}$. The average drying temperature was the average between the bottom and top temperatures of the piled nuts on the drying platform. The drying temperatures generated were below $100^{\circ} \mathrm{C}$ thus producing uncharred copra. The evaporation of water from the coconut meat was gradual.

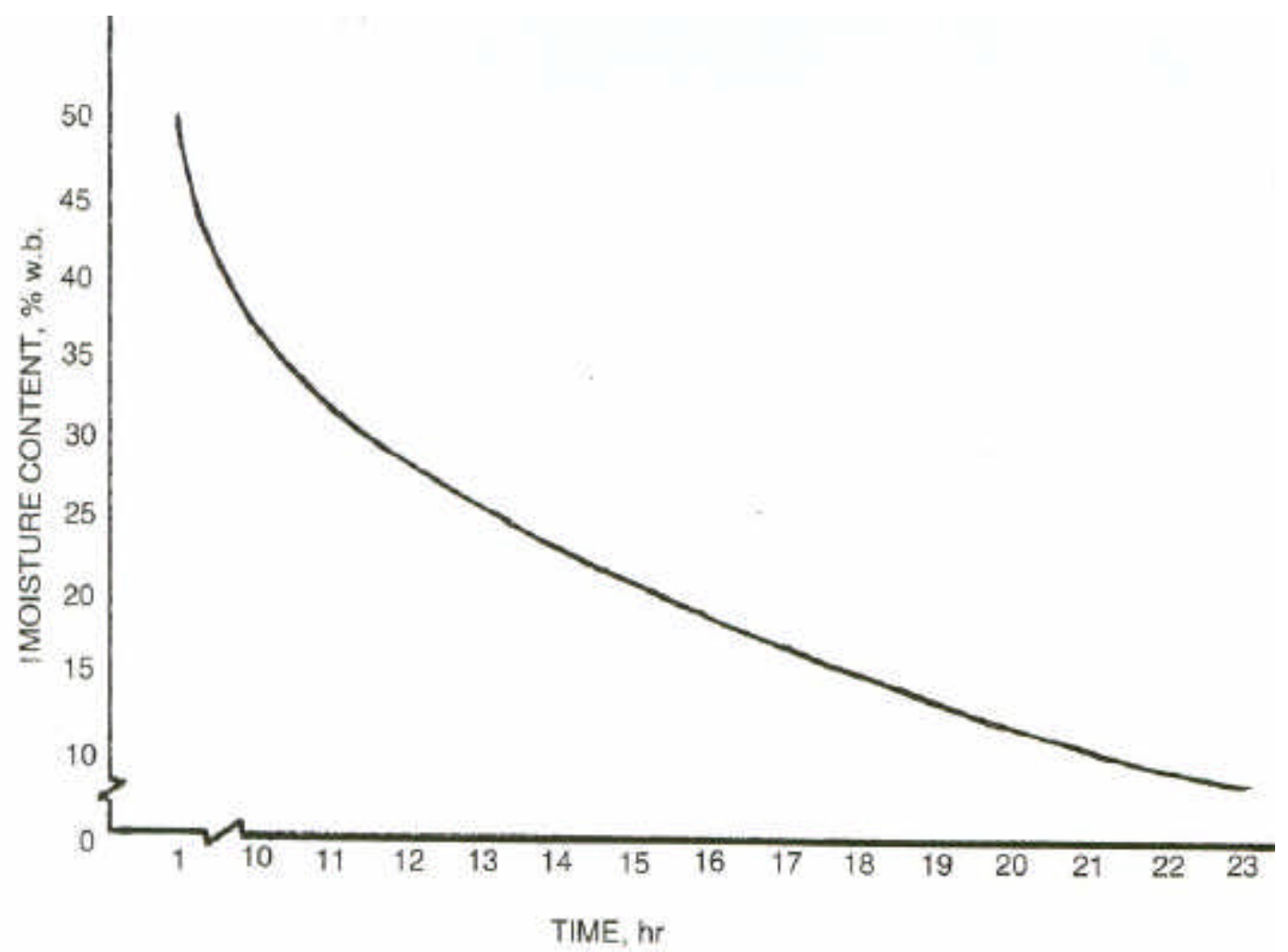

Fig. 5. The drying curve of the coconut meat. 
The fuel used to dry the 2,000 nuts were the husks of the nuts being dried. The moisture content was quite high. The average moisture content of the husks was $54.11 \%$. All husks of the 2,000 nuts were not consumed. It only consumed 1,243 pieces equivalent to $668.8 \mathrm{~kg}$ or $62.15 \%$. The remaining husks could still be used for other purposes.

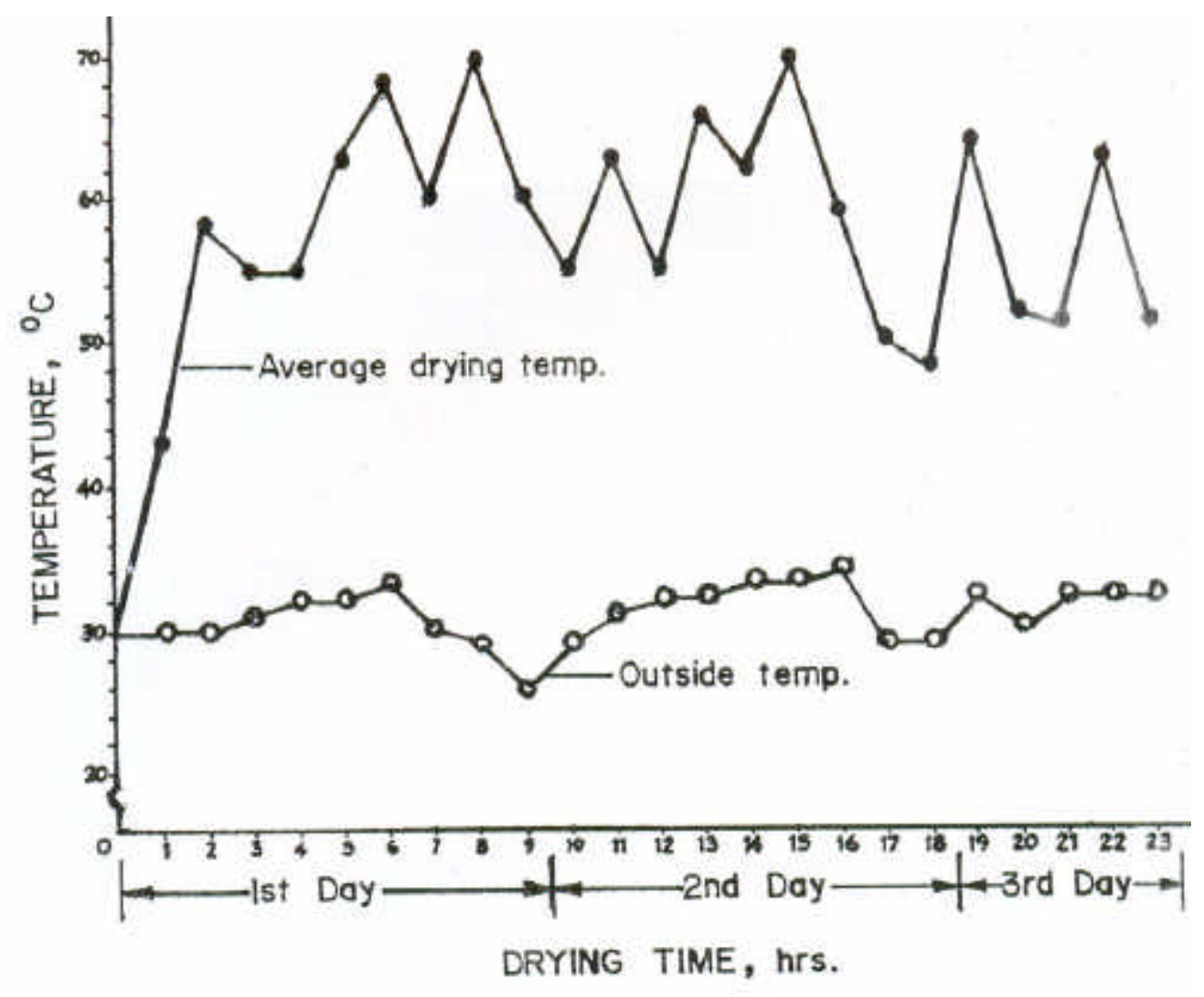

Fig. 6. Temperatures generated during drying.

This dryer is intended for husks as fuel so that the farmers can earn additional income from their coconut shells especially when made into charcoal. Lozada (1987) designed a portable copra dryer using coconut shells, corn cobs, peanut hulls, wood chips, etc. except coconut husks as fuel. Even the presence of other dryers like VISCA Copra dryer with 700 nuts capacity only utilizing coconut shells on chute as fuel, the farmers still asked the author for an efficient copra dryer design that can accommodate 2,000 nuts using husks as fuel. It is common in the locality making coconut shells into charcoal especially with the presence of low cost and simple techniques with high charcoal recovery using pit method by Sudaria $(1984,1986,1989)$.

The quality of copra produced was superior compared to the copra produced from direct-type dryer. The color ranged from light to dark brown (Fig. 7). However, the quality of copra produced from the indirect-type dryer is more superior than any other types of dryer. The problems of this dryer were low thermal efficiency and very expensive (Escalante, et al. 1977). For the indirect dryer, if the farmer is drying 2,000 nuts, the husks of 2,000 nuts are not enough to lower the moisture to even $9 \%$. 


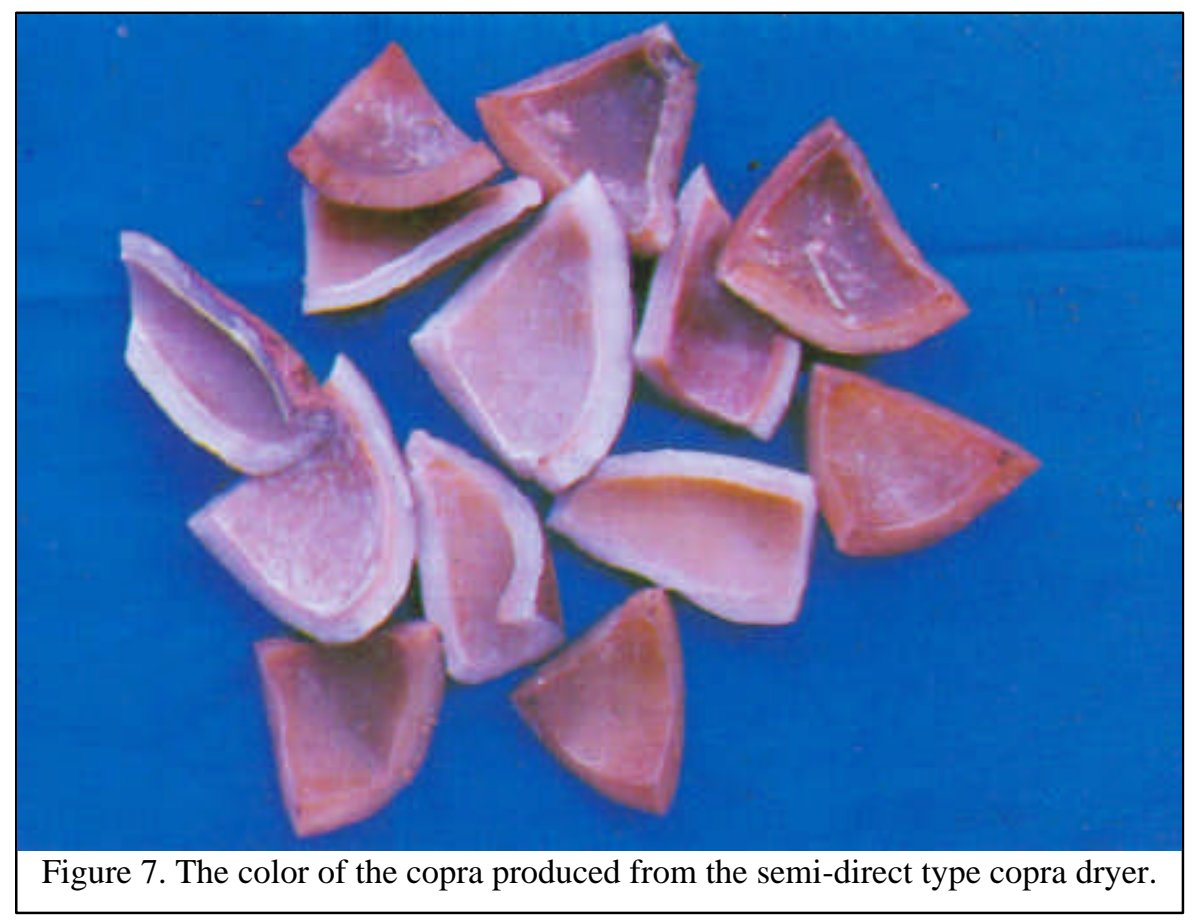

\section{RECOMMENDATION}

Based from the positive comments of the users, this particular design of the semi-direct type copra dryer is recommended for use by other coconut farmers.

\section{LITERATURE CITED}

Escalante, M. C., J. R. Rosillo, and H. C. Celino. 1977. Coconut Drying Central Pilot Studies (Phase One). Terminal Report. PCRDF-Funded Research Project. Department of Agricultural Engineering and Applied Mathematics. VISCA, Baybay, Leyte.

Lozada, E. P. 1987. The Los Banos Multicrop Dryer. Philippine Coconut Research and Development Foundation, Inc. $3^{\text {rd }}$ floor, Philcoa Building, Diliman, Quezon City, Philippines.

Ly, T. and E. A. Hinay. 1979. Copra Drying. 1. Comparison Between the Recommencled Practice and Farmers' Practice of Splitted-Nut Arrangement Before Drying. Annals of Tropical Research. Vol. 1. Number 2.

Suclaria, E. E. 1984. Productional of Charcoal from Coconut Shell, Husk, and Husk with Shell Using Pit Method. RCRC Annual Report. 1984.

. 1986. Design, Construction, andd Evaluation of Pit for Coconut Shell Charcoal Production. Philippine Agricultural Engineering Journal. Vol XVII. 3rd \& 4th Quarters.

. 1989. Village-Level Energy Utilization of Copra Production By-Products in Eastern Visayas, Philippines. Coconut Research and Development. Vol. V No. 2, Asian and Pacific Coconut Community, Jakarta, Indonesia. 